\title{
The immunogenicity to the first anti-TNF therapy determines the outcome of switching to a second anti-TNF therapy in spondyloarthritis patients
}

Chamaida Plasencia 1*, Dora Pascual-Salcedo², Sara García-Carazo', Leticia Lojo', Laura Nuño', Alejandro Villalba', Diana Peiteado ${ }^{1}$, Florencia Arribas² , Jesus Díez ${ }^{3}$, Maria Teresa López-Casla², Emilio Martín-Molaª and Alejandro Balsa ${ }^{1}$

\begin{abstract}
Introduction: Anti-TNF drugs have proven to be effective against spondyloarthritis (SpA), although 30\% of patients fail to respond or experience adverse events leading to treatment discontinuation. In rheumatoid arthritis, the presence of anti-drug antibodies (ADA) against the first TNF inhibitor influences the outcome after switching. Our aim was to assess whether the response to a second anti-TNF drug is related to the previous development of ADA to the first anti-TNF drug SpA patients.
\end{abstract}

Methods: Forty-two SpA patients began a second anti-TNF drug after failing to respond to the first anti-TNF therapy. Clinical activity was assessed by the Ankylosing Spondylitis Disease Activity Score (ASDAS) at baseline (at the beginning of the first and second anti-TNF therapy) and at 6 months after switching. The drug and ADA levels were measured by ELISA before each administration.

Results: All patients were treated with anti-TNF drugs and mainly due to inefficacy were switched to a second anti-TNF drug. Eleven of 42 (26.2\%) developed ADA during the first biologic treatment. At baseline, no differences in ASDAS were found in patients with or without ADA to the first anti-TNF drug $(3.52 \pm 1.03$ without ADA vs. 3.14 \pm 0.95 with ADA, $p=0.399)$ and to the second anti-TNF drug $(3.36 \pm 0.94$ without ADA vs. $3.09 \pm 0.91$ with ADA, $p$ $=0.466)$. At 6 months after switching, patients with previous ADA had lower disease activity $(1.62 \pm 0.93$ with ADA vs. $2.79 \pm 1.01$ without $A D A, p=0.002$ ) and most patients without ADA had high disease activity state by the ASDAS (25 out of 31 (80.6\%) without ADA vs. 3 out of 11 (27.3\%) with ADA, $p=0.002$ ).

Conclusions: In SpA the failure to respond to the first anti-TNF drug due to the presence of ADA predicts a better clinical response to a second anti-TNF drug.

\section{Introduction}

Spondyloarthritis (SpA) describes a group of diseases including ankylosing spondylitis (AS), psoriatic SpA, SpA related to inflammatory bowel disease (IBD), reactive arthritis, a subgroup of juvenile idiopathic arthritis and nonradiographic axial spondyloarthritis [1]. Several

\footnotetext{
* Correspondence: chamiplasencia@hotmail.com

'Rheumatology Department, La Paz University Hospital-Idipaz, Paseo la Castellana 261, Madrid, PC 28046, Spain

Full list of author information is available at the end of the article
}

studies have demonstrated the efficacy of biological agents, such as anti-TNF $\alpha$ drugs, for treating SpA patients [2-9].

The available anti-TNF drugs differ in chemical structure, half-life, route of application and capacity to induce immunogenicity, and they also have somewhat different mechanisms of action [10,11]. Although the efficacy of anti-TNF drugs against SpA has been shown in large, randomised clinical trials [6,12-16], it is known that some patients fail to respond to treatment or experience adverse events necessitating treatment 
discontinuation $[11,17]$. Part of this treatment failure can be explained by the development of anti-drug antibodies (ADA) [17-20].

To date, only two studies have been published that correlate the clinical response and immunogenicity to anti-TNF drugs in rheumatoid arthritis (RA) patients who switched to a second anti-TNF drug [21,22]. In these studies, RA patients with ADA against the first anti-TNF drug have been shown to have a better clinical response after switching to a second anti-TNF therapy than patients who did not develop ADA against the first anti-TNF drug $[21,22]$. Until now, no data have been published about the association between immunogenicity to the first anti-TNF drug and the clinical response after switching to a second anti-TNF drug in SpA patients. In this study, we analysed whether the clinical response to a second anti-TNF drug is conditioned by the development of ADA against the first anti-TNF drug in a group of SpA patients.

\section{Materials and methods}

\section{Patients and sera}

A total of $42 \mathrm{SpA}$ patients (27 AS, 10 nonradiographic axial SpA, 2 SpA associated with IBD, 2 psoriatic SpA and $1 \mathrm{SpA}$ secondary to reactive arthritis) without previous biological treatment were included. All of these patients had axial involvement and most of them had some peripheral articular manifestation as dactylitis, enthesopathy, monoarthritis and oligoarthritis (28/42 (66.7\%) SpA patients: 13 AS, 10 nonradiographic axial SpA, 2 psoriatic SpA, 2 SpA related to IBD and 1 reactive arthritis. The patients were enrolled at the Department of Rheumatology of La Paz University Hospital. This was an ambispective observational study that was approved by the La Paz Hospital Ethics Committee, and all patients provided informed written consent. The retrospective study period covered the years 2005 to 2008, and the prospective study period covered 2009 to 2011. All of the AS patients fulfilled the New York revised criteria for AS [23]. The psoriatic arthritis patients fulfilled the GRAPPA group criteria [24].

All patients received anti-TNF drugs as a first biological treatment (infliximab (Ifx), adalimumab (Ada) and etanercept (Etn)) and later switched to a second antiTNF drug (Ifx, Ada, Etn and golimumab (Gol)). The selection of all anti-TNF drugs was left to the discretion of the physician, with consideration of patient characteristics, type of disease, and patient preference. Owing to the observational design of the study, no specific criteria for drug withdrawal were required, and the diagnoses of treatment failure and adverse events were based on the judgement of the treating physician. Ifx was administered intravenously at $5 \mathrm{mg} / \mathrm{kg}$ at 0,2 and 6 weeks and every 8 weeks thereafter, and the remaining anti-TNF drugs were administrated subcutaneously (Ada, $40 \mathrm{mg} / 2$ weeks; Etn, $50 \mathrm{mg} /$ week; and Gol, $50 \mathrm{mg} / \mathrm{month}$ ).

Disease activity was measured by the Ankylosing Spondylitis Disease Activity Score (ASDAS) [25,26] and was assessed at baseline and every 6 months. At the time of inclusion, all patients had evidence of active spinal disease, as indicated by a mean ASDAS of $3.42 \pm$ 1.01. Clinically important improvement was defined as change in ASDAS $\geq 1.1$ [26]. Data related to the clinical activity in the retrospective period were obtained from our database of patients on biological therapy.

Blood samples were collected a maximum of 24 hours before biological drug administration for subcutaneous anti-TNF or just before intravenous infusion for Ifx. Precise timing was required to compare the results because the drug levels in the serum can become undetectable over longer time intervals as a result of normal drug pharmacokinetics rather than the formation of immunocomplexes with ADA. All sera, including those of the retrospective period, were stored at $-20^{\circ} \mathrm{C}$ until the drug and ADA concentrations were measured.

\section{Measurement of drug and anti-drug antibody concentrations}

The serum drug concentrations (Ifx, Ada and Etn) were determined by sandwich ELISA, as described previously [27-29]. Serum drug levels were considered positive for Ifx if $>10 \mathrm{ng} / \mathrm{ml}$, for Ada if $>5 \mathrm{ng} / \mathrm{ml}$ and for Etn if $>30$ $\mathrm{ng} / \mathrm{ml}$.

Serum ADA levels (antibodies to Ifx, antibodies to Ada and antibodies to Etn) were detected using a twosite (bridging) ELISA, as previously described [27-29]. The cutoff value for the presence of antibodies to Ifx was established at $50 \mathrm{AU} / \mathrm{ml}$, for antibodies to Ada at $10 \mathrm{AU} / \mathrm{ml}$ and for antibodies to Etn at $50 \mathrm{AU} / \mathrm{ml}$.

To determine the cutoff value of each assay, sera from 150 healthy controls and from 100 RA patients without anti-TNF treatment (70\% positive for rheumatoid factor) were studied. The mean \pm 6 standard deviations was used to establish cutoff points.

\section{Statistical analysis}

The statistical analyses were performed using the Statistical Package for the Social Sciences, version 11.0 (SPSS, Chicago, IL, USA). Descriptive statistics included the mean and standard deviation or the median and interquartile range. Differences in baseline characteristics were assessed using Pearson's chi-square test and Fisher's exact test for ordinal variables and using the MannWhitney $U$ test for continuous variables. The continuous data were compared between groups using the Mann-Whitney U test. Statistical significance was calculated using the log-rank test, and $\mathrm{p}<0.05$ was considered significant. 


\section{Results}

\section{Patient characteristics}

A total of $42 \mathrm{SpA}$ patients were enrolled in this study with a mean \pm standard deviation age of $49.6 \pm 10.4$ years at the time of inclusion, and 23 (54.8\%) were men. The baseline demographic and clinical characteristics of the global patient population, categorised according to future ADA development against the first anti-TNF therapy, are shown in Table 1 . No differences in patient characteristics were present at baseline between those who later developed ADA and those who did not (Table 1).

\section{Immunogenicity in relation to biological therapy}

All 42 patients were treated with an anti-TNF drug as the first biologic therapy (20 with Ifx, 5 with Ada and 17 with Etn) and were switched to a second anti-TNF treatment (9 Ifx, 19 Ada, 8 Etn and 6 Gol) due to inefficacy (39 out of 42 patients, $92.8 \%$; 11 of them ADApositive) and/or adverse events (8 out of 42 patients, $19 \%)$. Of the eight patients who withdrew due to adverse events, three had been treated with Ifx (all of them with ADA and clinical inefficacy, having infusion-related reactions) and five with Etn (two out of five patients also had clinical inefficacy, all of them having local injection reaction and/or pruritus).

ADA were detected in $11(26.2 \%)$ patients $(7 / 27$ (25.9\%) AS, 3/10 (30\%) undifferentiated SpA and 1/2 (50\%) SpA related to IBD) during treatment with the

Table 1 Demographic characteristics of 42 spondyloarthritis patients

\begin{tabular}{|c|c|c|c|c|}
\hline Characteristic & $\begin{array}{l}\text { Total (42 } \\
\text { patients) }\end{array}$ & $\begin{array}{l}\text { Without ADA } \\
\text { (31 patients) }\end{array}$ & $\begin{array}{l}\text { With ADA } \\
\text { (11 patients) }\end{array}$ & $\begin{array}{l}p \\
\text { value }\end{array}$ \\
\hline Sex, male & $23(54.8 \%)$ & $16(51.6 \%)$ & $7(63.6 \%)$ & 0.726 \\
\hline Age & $\begin{array}{l}49.60 \pm \\
10.46\end{array}$ & $51.26 \pm 10.08$ & $44.91 \pm 10.53$ & 0.084 \\
\hline HLA-B27-positive ${ }^{a}$ & $\begin{array}{l}23 / 36 \\
(64 \%)\end{array}$ & $17 / 27(63 \%)$ & $6 / 9(66.7 \%)$ & 0.841 \\
\hline $\begin{array}{l}\text { Disease duration } \\
\text { (years) }\end{array}$ & $\begin{array}{l}12.24 \pm \\
8.23\end{array}$ & $11.61 \pm 8.04$ & $14 \pm 8.92$ & 0.416 \\
\hline Baseline ASDAS & $\begin{array}{l}3.42 \pm \\
1.01\end{array}$ & $3.52 \pm 1.03$ & $3.14 \pm 0.95$ & 0.399 \\
\hline \multicolumn{5}{|l|}{$\begin{array}{l}\text { Concomitant } \\
\text { treatment }\end{array}$} \\
\hline Methotrexate & $9(21.5 \%)$ & $8(25.8 \%)$ & $1(9.1 \%)$ & 0.498 \\
\hline $\begin{array}{l}\text { Other } \\
\text { DMARDs }\end{array}$ & $10(23.8 \%)$ & $5(16.1 \%)$ & $5(45.4 \%)$ & 0.115 \\
\hline $\begin{array}{l}\text { Methotrexate } \\
+ \text { other }\end{array}$ & $1(4,7 \%)$ & 2 (6.4\%) & $0(0 \%)$ & 0.599 \\
\hline \multicolumn{5}{|l|}{ DMARDs } \\
\hline Monotherapy & $21(50 \%)$ & $16(51.7 \%)$ & $5(45.5 \%)$ & 0.126 \\
\hline $\begin{array}{l}\text { Corticosteroid } \\
\text { therapy }\end{array}$ & $15(35.7 \%)$ & $9(29 \%)$ & $6(50 \%)$ & \\
\hline
\end{tabular}

Data presented as $n$ (\%) or mean \pm standard deviation. ADA, anti-drug antibodies; ASDAS, Ankylosing Spondylitis Disease Activity Score; DMARD, disease-modifying anti-rheumatic drug. ${ }^{a} n /$ total number (\%). first anti-TNF drug and were more frequent in patients treated with Ifx (9 (81.8\%) with Ifx, $2(18.2 \%)$ with Ada, $0(0 \%)$ with Etn, $p=0.006)$. ADA appeared mainly within the first year of anti-TNF therapy (mean \pm standard deviation: $12.89 \pm 5.92$ months), except for five patients in whom ADA were detected at 18 months (2 patients), 20 months (2 patients) and 28 months (1 patient). At 6 months after switching to the second antiTNF drug, ADA were detected in only two patients treated with Ifx, who had not previously developed antibodies against the first anti-TNF drug. The drug and ADA concentrations were not evaluated for Gol.

Most patients without ADA (28/31) against the first anti-TNF drug had clinical inefficacy and detectable serum drug levels just before the switch to the second anti-TNF drug (median (interquartile range): 3,008 (680 to 3,076$) \mathrm{ng} / \mathrm{ml}$ for Ifx, $3,072(2,048$ to 4,096$) \mathrm{ng} / \mathrm{ml}$ for Ada, 1,111 (683 to 2,077) $\mathrm{ng} / \mathrm{ml}$ for Etn), so these patients were considered as having a primary inefficacy. Only three patients treated with Etn without detectable antibodies before switching did not have loss of efficacy and they were switched due only to adverse events. Furthermore, all of 11 patients with ADA against the first anti-TNF treatment had loss of efficacy and undetectable drug levels before switching, so they were classified as having secondary inefficacy related to development of immunogenicity.

\section{Clinical response in relation to immunogenicity}

At baseline, no differences in disease activity were observed between patients who did or did not later develop ADA against the first anti-TNF drug (baseline ASDAS first anti-TNF: $3.52 \pm 1.03$ without ADA vs. $3.14 \pm 0.95$ with ADA, $p=0.399$; baseline ASDAS second anti-TNF: $3.36 \pm 0.94$ without ADA vs. $3.09 \pm 0.91$ with $\mathrm{ADA}, p=0.466)$. Also, there were no differences in clinical activity at baseline to the first and second antiTNF drugs in patients with and without ADA (without ADA: $3.52 \pm 1.03$ to the first anti-TNF vs. $3.36 \pm 0.94$ to the second anti-TNF, $p=0.383$; with ADA: $3.14 \pm$ 0.95 to the first anti-TNF vs. $3.09 \pm 0.91$ to the second anti-TNF, $p=0.922$ ).

At 6 months after switching, the patients who had developed ADA against the first anti-TNF drug had lower disease activity, as measured by the ASDAS $(1.62$ \pm 0.93 with $\mathrm{ADA}$ vs. $2.79 \pm 1.01$ without $\mathrm{ADA}, p=$ 0.002 ) (Figure 1), and more patients had inactive disease (4 out of $11(36.4 \%)$ with ADA vs. 1 out of 31 (3.2\%) without ADA, $p=0.002$ ) (Figure 2). After 6 months of switching, most patients without ADA against the first anti-TNF drug were classified as being in a high or very high disease activity state by the ASDAS (25 out of 31 (80.6\%) without ADA vs. 3 out of $11(27.3 \%)$ with ADA, $p=0.002$ ) (Figure 2). 


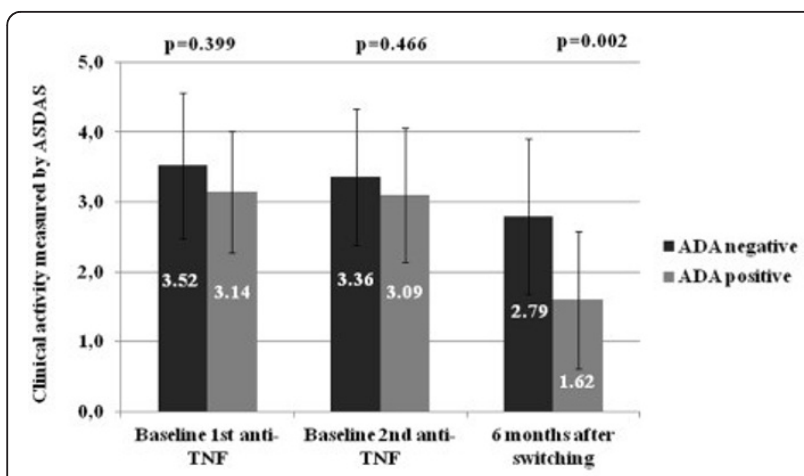

Figure 1 Association between clinical activity (Ankylosing Spondylitis Disease Activity Score) and immunogenicity. Ankylosing Spondylitis Disease Activity Score (ASDAS; mean \pm standard deviation) measured at baseline (first and second anti-TNF drugs) and at 6 months after switching to a second anti-TNF drug in patients who did or did not develop anti-drug antibodies (ADA) against the first anti-TNF drug.

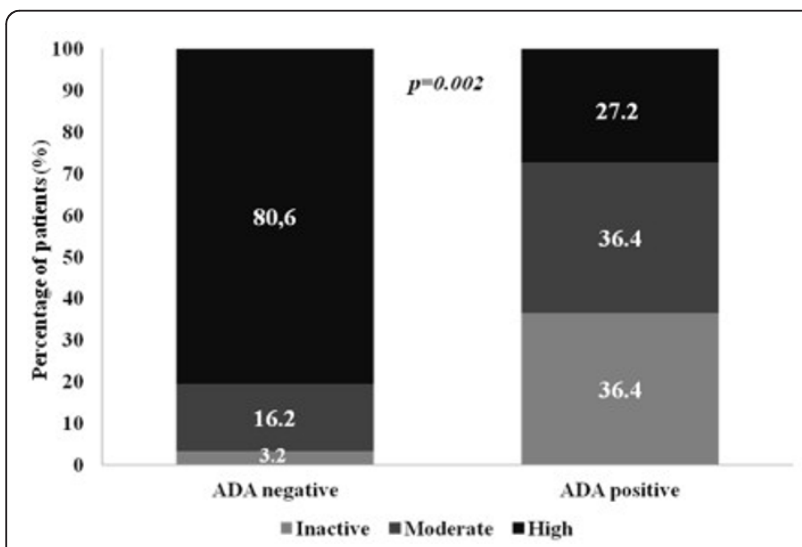

Figure 2 Association between anti-drug antibody status and clinical activity (Ankylosing Spondylitis Disease Activity Score) after switching. Clinical activity classified into inactive (light shading), moderate (medium shading) and high/very high activity (dark shading), according to Ankylosing Spondylitis Disease Activity Score criteria, 6 months after switching to a second anti-TNF drug in patients who had developed anti-drug antibodies (ADA) against the first anti-TNF drug.

At 6 months after switching we observed a greater clinical improvement, as measured by change in ASDAS, in patients with ADA as compared with those without ADA $(1.49 \pm 1.27$ with ADA vs. $0.56 \pm 1.01$ without ADA, $p=0.014$ ) (Figure 3). A total of 13 patients achieved clinically relevant improvement, and clinical improvement was more frequent in patients who had developed ADA (8t out of 11 (72.7\%) with ADA vs. 5 out of $31(16.1 \%)$ without ADA, $p=0.001)$. Three out of the five patients without ADA who had an important clinical improvement after switching were treated with Etn as the first anti-TNF drug and the reason for change to a second anti-TNF drug was adverse effects.

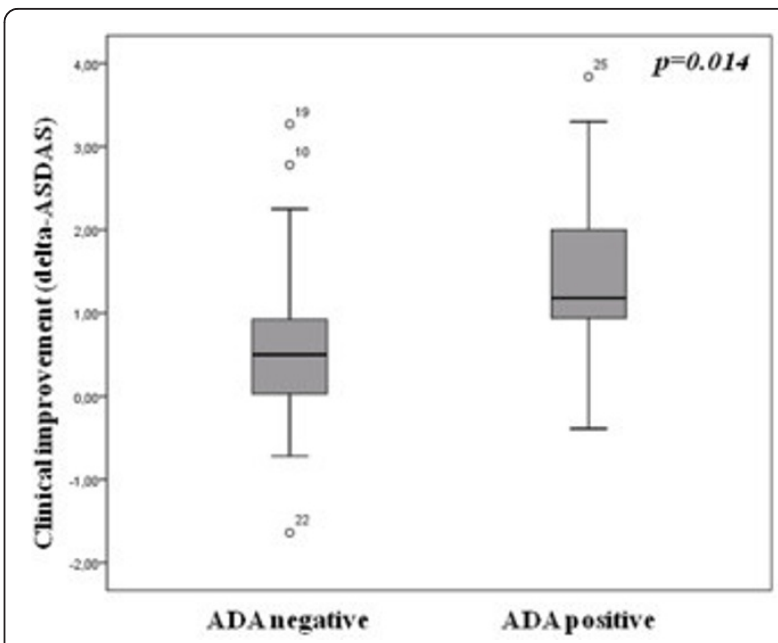

Figure 3 Association between clinical improvement (change in Ankylosing Spondylitis Disease Activity Score) and immunogenicity. Change in Ankylosing Spondylitis Disease Activity Score (delta-ASDAS) measured 6 months after switching in spondyloarthritis patients who presented or not anti-drug antibodies (ADA) against the first anti-TNF. Data shown as interquartile ranges ( $p 75$, upper edge; p25, lower edge; p50, midline of the box).

When a subanalysis is performed taking only the group of patients with AS $(n=27)$, we observed that our results in relation to clinical activity and immunogenicity are consistent with those observed analysing all 42 patients. At baseline of the first and second anti-TNF drugs, no differences were seen in clinical activity (ASDAS) between patients with and without ADA (baseline first anti-TNF: $3.61 \pm 1.11$ without ADA vs. $3.57 \pm 0.83$ with $\mathrm{ADA}, p=0.929$; baseline second antiTNF: $3.43 \pm 0.77$ without ADA vs. $2.87 \pm 1.01$ with ADA, $p=0.136)$. However, 6 months after switching the clinical activity was lower in patients with previous ADA $(2.78 \pm 1.05$ without ADA vs. $1.38 \pm 0.75$ with ADA, $p=0.0 .004$ ).

No differences were observed in clinical activity and clinical improvement between patients treated with a second anti-TNF drug with a mAb or fusion protein (ASDAS after 6 months of switching: $2.47 \pm 1.12$ with $\mathrm{mAb}$ vs. 2.53 \pm 1.11 with fusion protein, $p=0.908$; change in ASDAS after 6 months of switching: $0.73 \pm 1.17$ with $\mathrm{mAb}$ vs. 1.13 \pm 1.03 with fusion protein, $p=0.372$ ).

\section{Discussion}

In this article we studied the role of immunity against a first anti-TNF drug in the short-term response to a second anti-TNF drug in a group of SpA patients. We show that patients in whom drug discontinuation was associated with ADA development achieved a better clinical response at 6 months after switching than patients who had not developed ADA. 
Anti-TNF drugs are the only biological therapies available to treat SpA patients with an inadequate response to conventional treatment, and their efficacy has been demonstrated in several randomised placebo-controlled studies [2-9]. However, a number of patients fail to respond or experience adverse events necessitating treatment discontinuation $[11,17,20,30,31]$. Thus, it is crucial to know what factors predict the treatment response in SpA patients. Different predictors of a favourable response to the first anti-TNF drug have been reported in the literature, including shorter disease duration, younger age, HLA-B27 positivity, a lower Bath Ankylosing Spondylitis Functional Index score, higher C-reactive protein levels, a higher Bath Ankylosing Disease Activity Index score, male sex and the presence of peripheral arthritis and spinal inflammation on magnetic resonance imaging [18,32-39]. These data were not analysed in the present study because we only recruited SpA patients who had discontinued their first anti-TNF drug.

Only a few prospective studies have reported detailed information about switching to a second anti-TNF drug in AS patients $[11,40,41]$. One recent publication showed that switching to a second anti-TNF drug could benefit some AS patients, and up to one-third of patients achieved a good response [11]. However, disease activity at 3 months after switching was generally worse for switchers on their second anti-TNF drug than for nonswitchers [11]. Similar findings were observed in another study that included 1,250 AS patients, 326 of whom had previously received an anti-TNF drug [37]. In this study, anti-TNF-naive AS patients achieved greater treatment responses than patients who switched to a second anti-TNF drug [37].

The immunogenicity of biological therapies has been shown to influence secondary inefficacy in rheumatic diseases [17,28,42-52]. The frequency of ADA development in SpA patients varies between different studies (25.5 to $29 \%$ for antibodies to Ifx and $31 \%$ for antibodies to Ada) $[17,19,20,49-51]$. Several publications have described the relationship between the development of ADA and the clinical response in SpA patients [17,19,20,52-54]. In previous work conducted by our group, antibodies to Ifx were detected in $25.5 \%$ of SpA patients treated with Ifx, and a strong correlation was observed between antibodies to Ifx development and clinical response as measured by the ASDAS [49]. de Vries and colleagues observed that $31 \%$ of AS patients treated with Ada developed antibodies to Ada, and most of the patients did not reach an ASAS response after 6 months of treatment [20]. In this study, $26.2 \%(11 / 42)$ of patients who discontinued the first antiTNF drug had detectable ADA, and most had exhibited a good response to therapy until ADA development. However, the majority of SpA patients without ADA who switched to a new anti-TNF drug never demonstrated clinical improvement, and indeed they typically had a detectable serum drug concentration. These findings may suggest that TNF is not the main cytokine instigating disease activity in these patients or that symptoms in these patients are not related to the inflammatory activity of the disease.

Currently, there are only two reports that relate immunogenicity status to the first anti-TNF drug and its clinical response after switching to a second anti-TNF drug in RA patients [21,22]. Bartelds and colleagues observed that RA patients who had developed antibodies to Ifx against the first anti-TNF drug had no significant differences in clinical improvement after switching (change in Disease Activity Score for 28 joints) when compared with anti-TNF-naïve patients [21]. Nevertheless, switchers without antibodies to Ifx exhibited a significantly lower clinical response than naïve RA patients [21]. Similar findings were reported in a subsequently published study in RA patients (naïve and switchers) treated with Etn [22], which demonstrated that naïve patients and switchers with ADA had a greater clinical response than did patients who switched without ADA [22]. To our knowledge, the present work is the first report in which the influence of immunogenicity against the first anti-TNF drug has been associated with clinical activity after switching in SpA patients. As shown above, clinical improvement was greater in patients who switched after developing ADA, and 73\% of patients who achieved clinical improvement after switching had developed ADA to the previous anti-TNF drug.

Our study has several limitations. The number of patients is relatively small because all patients came from the same centre, and SpA patients are less likely than RA patients to discontinue anti-TNF drug $[38,41]$. However, our results show differences in treatment outcomes that are similar to those described after switching anti-TNF drugs in RA [21,22]. Furthermore, the decision to stop therapy or to change drugs was not standardised because it was based on the decision of the responsible rheumatologist. This may explain why disease activity, although not significantly different at the baseline of the second antiTNF drug, was slightly lower in the group that developed ADA, because patients are more sensitive to deterioration once they have previously improved, and the switch is performed at lower levels of disease activity. However, it is important to highlight that this is the pattern normally used to determine whether a therapeutic change is required in clinical practise. Finally, different anti-TNF drugs were used in the study, both as the first and the second anti-TNF therapies, which may have influenced the results. However, no differences in the effectiveness of the three most commonly used anti-TNFs have been demonstrated in clinical practice in AS [55], so it is unlikely that this would have affected the results. 


\section{Conclusions}

Similar to RA, the failure to respond to a first anti-TNF drug due to the development of ADA predicts a better clinical response to a second biological treatment in $\mathrm{SpA}$. The presence of ADA against the first anti-TNF drug is a determining factor for the response to a second anti-TNF drug. The study of the immunogenicity in biological treatment failure may help predict the response to a second biological treatment in SpA.

\section{Abbreviations \\ Ada: adalimumab; AS: ankylosing spondylitis; ASDAS: Ankylosing Spondylitis Disease Activity Score; ADA: anti-drug antibodies; ELISA: enzyme-linked immunosorbent assay; Etn: etanercept; Gol: golimumab; IBD: inflammatory bowel disease; Ifx: infliximab; mAb: monoclonal antibody RA: rheumatoid arthritis; SpA: spondyloarthritis; TNF: tumour necrosis factor.}

\section{Competing interests}

$A B$ has received fees from Roche, Schering-Plough, Wyeth, Abbott, BMS and UCB. EM-M is a consultant and a member of speakers' bureaus for Pfizer, MSD, UCB and Abbott. ChP, DP-S and LN have received speaker honoraria from Pfizer. All other authors declare that they have no competing interests.

\section{Authors' contributions}

ChP, DP-S, EM-M and AB wrote the article. DP-S, SGC, MTL-C and ChP carried out the data collection and databases. AV, DP, LN, LL, SGC, AB, EM-M and ChP performed the clinical evaluation of patients. JD, SGC and ChP performed the statistical analysis. DP-S and FA performed the laboratory assays. All authors read and approved the final manuscript.

\section{Acknowledgements}

This study was supported partially by unrestricted grants from Pfizer and the RETICS Program, and RD08/0075 (RIER) from the Instituto de Salud Carlos III.

\section{Authors' details}

'Rheumatology Department, La Paz University Hospital-Idipaz, Paseo la Castellana 261, Madrid, PC 28046, Spain. ${ }^{2}$ Immunology Unit, La Paz University Hospital-Idipaz, Paseo la Castellana 261, Madrid, PC 28046, Spain. ${ }^{3}$ Statistic Department, La Paz University Hospital-Idipaz, Paseo la Castellana 261, Madrid, PC 28046, Spain.

Received: 7 January 2013 Revised: 19 March 2013

Accepted: 26 July 2013 Published: 26 July 2013

\section{References}

1. Dougados M, Baeten D: Spondyloarthritis. Lancet 2011, 377:2127-2137.

2. Gorman JD, Sack KE, Davis JC Jr: Treatment of ankylosing spondylitis by inhibition of tumor necrosis factor alpha. N Engl J Med 2002, 346:1349-1356.

3. Davis JC Jr, van der HD, Braun J, Dougados M, Cush J, Clegg DO, Kivitz A, Fleischmann R, Inman R, Tsuji W: Recombinant human tumor necrosis factor receptor (etanercept) for treating ankylosing spondylitis: a randomized, controlled trial. Arthritis Rheum 2003, 48:3230-3236.

4. Brandt J, Haibel H, Sieper J, Reddig J, Braun J: Infliximab treatment of severe ankylosing spondylitis: one-year followup. Arthritis Rheum 2001, 44:2936-2937.

5. Brandt J, Haibel H, Cornely D, Golder W, Gonzalez J, Reddig J, Thriene W, Sieper J, Braun J: Successful treatment of active ankylosing spondylitis with the anti-tumor necrosis factor alpha monoclonal antibody infliximab. Arthritis Rheum 2000, 43:1346-1352.

6. Brandt J, Haibel H, Reddig J, Sieper J, Braun J: Successful short term treatment of severe undifferentiated spondyloarthropathy with the antitumor necrosis factor-alpha monoclonal antibody infliximab. J Rheumatol 2002, 29:118-122.

7. Braun J, Brandt J, Listing J, Zink A, Alten R, Burmester G, Golder W, Gromnica-Ihle E, Kellner H, Schneider M, Sörensen H, Zeidler H, Reddig J, Sieper J: Long-term efficacy and safety of infliximab in the treatment of ankylosing spondylitis: an open, observational, extension study of a three-month, randomized, placebo-controlled trial. Arthritis Rheum 2003, 48:2224-2233.

8. van den Bosch F, Kruithof E, Baeten D, De KF, Mielants H, Veys EM: Effects of a loading dose regimen of three infusions of chimeric monoclonal antibody to tumour necrosis factor alpha (infliximab) in spondyloarthropathy: an open pilot study. Ann Rheum Dis 2000, 59:428-433.

9. van den Bosch F, Kruithof E, Baeten D, Herssens A, De KF, Mielants H, Veys EM: Randomized double-blind comparison of chimeric monoclonal antibody to tumor necrosis factor alpha (infliximab) versus placebo in active spondylarthropathy. Arthritis Rheum 2002, 46:755-765.

10. Schellekens $\mathrm{H}$ : Bioequivalence and the immunogenicity of biopharmaceuticals. Nat Rev Drug Discov 2002, 1:457-462.

11. Lie E, van der HD, Uhlig T, Mikkelsen $K$, Rodevand E, Koldingsnes W, Kaufmann C, Kvien TK: Effectiveness of switching between TNF inhibitors in ankylosing spondylitis: data from the NOR-DMARD register. Ann Rheum Dis 2011, 70:157-163.

12. Braun J, Baraliakos X, Brandt J, Listing J, Zink A, Alten R, Burmester G, Gromnica-Ihle E, Kellner H, Schneider M, Sörensen H, Zeidler H, Sieper J: Persistent clinical response to the anti-TNF-alpha antibody infliximab in patients with ankylosing spondylitis over 3 years. Rheumatology (Oxford) 2005, 44:670-676.

13. de KF, Baeten D, Van den BF, Kruithof E, Mielants H, Veys EM: Infliximab in patients who have spondyloarthropathy: clinical efficacy, safety, and biological immunomodulation. Rheum Dis Clin North Am 2003, 29:463-479.

14. Brandt J, Khariouzov A, Listing J, Haibel H, Sorensen H, Rudwaleit M, Sieper J, Braun J: Successful short term treatment of patients with severe undifferentiated spondyloarthritis with the anti-tumor necrosis factoralpha fusion receptor protein etanercept. J Rheumatol 2004, 31:531-538.

15. Heldmann F, Brandt J, van der Horst-Bruinsma IE, Landewe R, Sieper J, Burmester GR, van den Bosch F, de Vlam K, Geusens P, Gaston H, Schewe S, Appelboom T, Emery P, Dougados M, Leirisalo-Repo M, Breban M, Listing J, Braun J: The European ankylosing spondylitis infliximab cohort (EASIC): a European multicentre study of long term outcomes in patients with ankylosing spondylitis treated with infliximab. Clin Exp Rheumatol 2011, 29:672-680.

16. Braun J, van der Horst-Bruinsma IE, Huang F, Burgos-Vargas R, Vlahos B, Koenig AS, Freundlich B: Clinical efficacy and safety of etanercept versus sulfasalazine in patients with ankylosing spondylitis: a randomized, double-blind trial. Arthritis Rheum 2011, 63:1543-1551.

17. de Vries MK, Wolbink GJ, Stapel SO, de VH, van Denderen JC, Dijkmans BA, Aarden LA, van der Horst-Bruinsma IE: Decreased clinical response to infliximab in ankylosing spondylitis is correlated with anti-infliximab formation. Ann Rheum Dis 2007, 66:1252-1254.

18. Hanauer SB, Feagan BG, Lichtenstein GR, Mayer LF, Schreiber S, Colombel JF, Rachmilewitz D, Wolf DC, Olson A, Bao W, Rutgeerts P: Maintenance infliximab for Crohn's disease: the ACCENT I randomised trial. Lancet 2002, 359:1541-1549.

19. de Vries MK, Wolbink GJ, Stapel SO, de Groot ER, Dijkmans BA, Aarden LA, van der Horst-Bruinsma IE: Inefficacy of infliximab in ankylosing spondylitis is correlated with antibody formation. Ann Rheum Dis 2007, 66:133-134.

20. de Vries MK, Brouwer E, van der Horst-Bruinsma IE, Spoorenberg A, van Denderen JC, Jamnitski A, Nurmohamed MT, Dijkmans BA, Aarden LA, Wolbink GJ: Decreased clinical response to adalimumab in ankylosing spondylitis is associated with antibody formation. Ann Rheum Dis 2009, 68:1787-1788.

21. Bartelds GM, Wijbrandts CA, Nurmohamed MT, Stapel S, Lems WF, Aarden L, Dijkmans BA, Tak PP, Wolbink GJ: Anti-infliximab and antiadalimumab antibodies in relation to response to adalimumab in infliximab switchers and anti-tumour necrosis factor naive patients: a cohort study. Ann Rheum Dis 2010, 69:817-821.

22. Jamnitski A, Bartelds GM, Nurmohamed MT, van Schouwenburg PA, van SD, Stapel SO, Dijkmans BA, Aarden L, Wolbink GJ: The presence or absence of antibodies to infliximab or adalimumab determines the outcome of switching to etanercept. Ann Rheum Dis 2011, 70:284-288.

23. van der LS, Valkenburg HA, Cats A: Evaluation of diagnostic criteria for ankylosing spondylitis. A proposal for modification of the New York criteria. Arthritis Rheum 1984, 27:361-368.

24. Ritchlin $C T$, Kavanaugh $A$, Gladman DD, Mease PJ, Helliwell $P$, Boehncke WH, de Vlam K, Fiorentino D, Fitzgerald O, Gottlieb AB, 
McHugh NJ, Nash P, Qureshi AA, Soriano ER, Taylor WJ: Treatment recommendations for psoriatic arthritis. Ann Rheum Dis 2009, 68:1387-1394

25. Lukas C, Landewe R, Sieper J, Dougados M, Davis J, Braun J, van der Linden S, van der Heijde D: Development of an ASAS-endorsed disease activity score (ASDAS) in patients with ankylosing spondylitis. Ann Rheum Dis 2009, 68:18-24.

26. Machado P, Landewé R, Lie E, Kvien TK, Braun J, Baker D, van der Heijde D: Ankylosing Spondylitis Disease Activity Score (ASDAS); defining cut-off values for disease activity state and improvement scores. Ann Rheum Dis 2011, 70:47-53.

27. Hart MH, de VH, Wouters D, Wolbink GJ, Killestein J, de Groot ER, Aarden LA, Rispens T: Differential effect of drug interference in immunogenicity assays. J Immunol Methods 2011, 372:196-203.

28. Pascual-Salcedo D, Plasencia C, Ramiro S, Nuno L, Bonilla G, Nagore D, Ruiz Del Agua A, Martínez A, Aarden L, Martín-Mola E, Balsa A: Influence of immunogenicity on the efficacy of long-term treatment with infliximab in rheumatoid arthritis. Rheumatology (Oxford) 2011, 50:1445-1452.

29. Wolbink GJ, Voskuyl AE, Lems WF, de GE, Nurmohamed MT, Tak PP, Dijkmans BA, Aarden L: Relationship between serum trough infliximab levels, pretreatment $C$ reactive protein levels, and clinical response to infliximab treatment in patients with rheumatoid arthritis. Ann Rheum Dis 2005, 64:704-707.

30. Arends S, Brouwer E, van der Veer E, Groen H, Leijsma MK, Houtman PM, Griep EN, Limburg PC, Kallenberg CG, Wolbink GJ, Brouwer E: The formation of autoantibodies to TNF-a blocking agents in relation to clinical response in patients with ankilosing spondylitis. Clin Exp Rheumatol 2010, 28:661-668.

31. de Vries MK, van der Horst-Bruinsma IE, Nurmohamed MT, Aarden LA, Aarden LA, Stapel SO, Peters MJ, van Denderen JC, Dijkmans BA, Wolbink GJ: Immunogenicity does not influence treatment with etanercept in patients with ankylosing spondylitis. Ann Rheum Dis 2009, 68:531-535.

32. Kristensen LE, Karlsson JA, Englund M, Petersson IF, Saxne T, Geborek P. Presence of peripheral arthritis and male sex predicting continuation of anti-tumor necrosis factor therapy in ankylosing spondylitis: an observational prospective cohort study from the South Swedish Arthritis Treatment Group Register. Arthritis Care Res (Hoboken) 2010, 62:1362-1369.

33. Stone MA, Payne U, Pacheco-Tena C, Inman RD: Cytokine correlate of clinical response patterns to infliximab treatment of ankylosing spondylitis. Ann Rheum Dis 2004, 63:84-87.

34. Rudwaleit M, Listing J, Brandt J, Braun J, Sieper J: Prediction of a major clinical response (BASDAI 50) to tumour necrosis factor alpha blockers in ankylosing spondylitis. Ann Rheum Dis 2004, 63:665-670.

35. Davis JC Jr, Van der Heijde DM, Dougados M, Braun J, Cush JJ, Clegg DO, Inman RD, de Vries T, Tsuji WH: Baseline factors that influence ASAS 20 response in patients with ankylosing spondylitis treated with etanercept. J Rheumatol 2005, 32:1751-1754.

36. Rudwaleit M, Schwarzlose S, Hilgert ES, Listing J, Braun J, Sieper J: MRI in predicting a major clinical response to anti-tumour necrosis factor treatment in ankylosing spondylitis. Ann Rheum Dis 2008, 67:1276-1281.

37. Rudwaleit M, Claudepierre P, Wordsworth P, Cortina EL, Sieper J, Kron M, Carcereri-De-Prati R, Kupper H, Kary S: Effectiveness, safety, and predictors of good clinical response in 1250 patients treated with adalimumab for active ankylosing spondylitis. J Rheumatol 2009, 36:801-808.

38. Pavelka K, Forejtova S, Stolfa J, Chroust K, Buresova L, Mann H, Vencovský J: Anti-TNF therapy of ankylosing spondylitis in clinical practice. Results from the Czech national registry ATTRA. Clin Exp Rheumatol 2009, 27:958-963.

39. Lord PA, Farragher TM, Lunt M, Watson KD, Symmons DP, Hyrich KL: Predictors of response to anti-TNF therapy in ankylosing spondylitis: results from the British Society for Rheumatology Biologics Register. Rheumatology (Oxford) 2010, 49:563-570.

40. Delaunay C, Farrenq V, Marini-Portugal A, Cohen JD, Chevalier X, Claudepierre P: Infliximab to etanercept switch in patients with spondyloarthropathies and psoriatic arthritis: preliminary data. J Rheumatol 2005, 32:2183-2185.

41. Carmona L, Gomez-Reino JJ: Survival of TNF antagonists in spondylarthritis is better than in rheumatoid arthritis. Data from the Spanish registry BIOBADAER. Arthritis Res Ther 2006, 8:R72.
42. Keystone EC, Kavanaugh AF, Sharp JT, Tannenbaum H, Hua Y, Teoh LS, Fischkoff SA, Chartash EK: Radiographic, clinical, and functional outcomes of treatment with adalimumab (a human anti-tumor necrosis factor monoclonal antibody) in patients with active rheumatoid arthritis receiving concomitant methotrexate therapy: a randomized, placebocontrolled, 52-week trial. Arthritis Rheum 2004, 50:1400-1411.

43. Sidiropoulos PI, Boumpas DT: Differential drug resistance to anti-tumour necrosis factor agents in rheumatoid arthritis. Ann Rheum Dis 2006, 65:701-703.

44. Haraoui B, Cameron L, Ouellet M, White B: Anti-infliximab antibodies in patients with rheumatoid arthritis who require higher doses of infliximab to achieve or maintain a clinical response. J Rheumatol 2006, 33:31-36.

45. Maini RN, Breedveld FC, Kalden JR, Smolen JS, Davis D, Macfarlane JD, Antoni C, Leeb B, Elliott MJ, Woody JN, Schaible TF, Feldmann M: Therapeutic efficacy of multiple intravenous infusions of anti-tumor necrosis factor alpha monoclonal antibody combined with low-dose weekly methotrexate in rheumatoid arthritis. Arthritis Rheum 1998, 41:1552-1563.

46. Radstake TR, Svenson M, Eijsbouts AM, van den Hoogen FH, Enevold C, van Riel PL, Bendtzen K: Formation of antibodies against infliximab and adalimumab strongly correlate with functional drug levels and clinical responses in rheumatoid arthritis. Ann Rheum Dis 2009, 68:1739-1745.

47. Wolbink GJ, Vis M, Lems W, Voskuyl AE, de GE, Nurmohamed MT, Stapel S, Tak PP, Aarden L, Dijkmans B: Development of antiinfliximab antibodies and relationship to clinical response in patients with rheumatoid arthritis. Arthritis Rheum 2006, 54:711-715.

48. Svenson M, Geborek P, Saxne T, Bendtzen K: Monitoring patients treated with anti-TNF-alpha biopharmaceuticals: assessing serum infliximab and anti-infliximab antibodies. Rheumatology (Oxford) 2007, 46:1828-1834.

49. van der Bijl AE, Breedveld FC, Antoni CE, Kalden JR, Kary S, Burmester GR, Beckmann C, Unnebrink K, Kupper H: An open-label pilot study of the effectiveness of adalimumab in patients with rheumatoid arthritis and previous infliximab treatment: relationship to reasons for failure and anti-infliximab antibody status. Clin Rheumatol 2008, 27:1021-1028.

50. van den Bemt BJ, den Broeder AA, Snijders GF, Hekster YA, van Riel PL, Benraad B, Wolbink GJ, van den Hoogen FH: Sustained effect after lowering high-dose infliximab in patients with rheumatoid arthritis: a prospective dose titration study. Ann Rheum Dis 2008, 67:1697-1701.

51. Bendtzen K, Geborek P, Svenson M, Larsson L, Kapetanovic MC, Saxne T: Individualized monitoring of drug bioavailability and immunogenicity in rheumatoid arthritis patients treated with the tumor necrosis factor alpha inhibitor infliximab. Arthritis Rheum 2006, 54:3782-3789.

52. Plasencia C, Pascual-Salcedo D, Nuno L, Bonilla G, Villalba A, Peiteado D, Díez J, Nagore D, del Agua AR, Moral R, Martin-Mola E, Balsa A: Influence of immunogenicity on the efficacy of long-term treatment of spondyloarthritis with infliximab. Ann Rheum Dis 2012, 71:1955-1960.

53. Ducourau E, Mulleman D, Paintaud G, Chu Miow LD, Lauferon F, Ternant D, Watier $\mathrm{H}$, Goupillel P: Antibodies toward infliximab are associated with low infliximab concentration at treatment initiation and poor infliximab maintenance in rheumatic diseases. Arthritis Res Ther 2011, 13:R105.

54. Aybay C, Ozel S, Aybay C: Demonstration of specific antibodies against infliximab induced during treatment of a patient with ankylosing spondylitis. Rheumatol Int 2006, 26:473-480.

55. Glintborg B, Ostergaard M, Krogh NS, Dreyer L, Kristensen HL, Hetland ML: Predictors of treatment response and drug continuation in 842 patients with ankylosing spondylitis treated with anti-tumour necrosis factor: results from 8 years' surveillance in the Danish nationwide DANBIO registry. Ann Rheum Dis 2010, 69:2002-2008.

\section{doi:10.1186/ar4258}

Cite this article as: Plasencia et al:: The immunogenicity to the first antiTNF therapy determines the outcome of switching to a second anti-TNF therapy in spondyloarthritis patients. Arthritis Research \& Therapy 201315 R79. 